九州大学学術情報リポジトリ

Kyushu University Institutional Repository

\title{
A study on Trend of Korean Forestry ODA Allocation
}

Yoon, Jun-Young

Department of Vegetable Crops, Poznan University of Life Sciences

Park, Gwan-Soo

Department of Forest Resources, Chungnam National University

Lee, Sang-Jin

Department of Forest Resources, Chungnam National University

Lee, Si-Young

Professional Graduate School of Disaster Prevention, Kangwon National University

他

https://doi.org/10.5109/1434374

出版情報：九州大学大学院農学研究院紀要. 59 (1)，pp.13-18，2014-02-28. Faculty of Agriculture， Kyushu University

バージョン :

権利関係 : 


\title{
A study on Trend of Korean Forestry ODA Allocation
}

\author{
Jun-Young YOON ${ }^{1}$, Gwan-Soo PARK ${ }^{1 *}$, Sang-Jin LEE ${ }^{1}$, \\ Si-Young LEE ${ }^{2}$ and Shoji OHGA
}

\author{
Laboratory of Forest Resources Management, Division of Forest Environmental \\ Sciences, Department of Agro-Environmental Sciences, Faculty of Agriculture, \\ Kyushu University, Fukuoka 811-2415, Japan \\ (Received September 24, 2013 and accepted November 11, 2013)
}

\begin{abstract}
This study was to investigate trend of Korean Forestry ODA Allocation (KFOA). To achieve this research objective, firstly, the proportion of forestry ODA allocation by recipient continents was compared between Korea and OECD/DAC (The organization for Economic co-operation and Development's Development Assistance Committee) through OECD statistic data. Secondly, factors which may affect KFOA were analyzed. Distances, status of bilateral forestry cooperation, amount of forestry product import \& export, corruption index, forest area, forest conversion rate, GDP per capital, and income level of each 24 recipient country were selected as possible factors. Bilateral forest cooperation turned out the most determinant factor among the others in this study. Ninety percent of Korean forestry ODA amount from 2006-2011 was allocated to 4 countries with bilateral forestry cooperation which were Mongolia, China, Indonesia, and Philippine. And $98 \%, 0.4 \%$ of Korean forestry ODA was given to Asia and Africa, respectively while OECD/DAC constantly increased forestry ODA for Africa by $26 \%$ during 1999-2011. Accordingly, it indicated that Korean forestry ODA was selective in targeting Asia and recipient countries with bilateral forestry cooperation.
\end{abstract}

Key words: forest, ODA, allocation trend, selectivity

\section{INTRODUCTION}

Deforestation, degradation of forest, and desertification are influential on climate change and threat livelihood of forest dependent people in developing countries. In developing countries, $22 \%$ of whole forest area which is 2.2 billion ha is managed by indigenous and local people depending on their forest (White and Martin, 2002). They mostly earn the lowest incomes and live in poor condition (Arnold, 2001). In addition, forest dependent people are vulnerable to natural disasters from climate change, inappropriate government forest management policy, income reduction, and instable tenure right. For this reason, international organizations and main donor countries have implemented forestry aid for past 60 years.

However, some researcher pointed out that forestry ODA did not help their recipient countries resolve chronic problem related to forestry despite of its long aid history. They criticized that purpose of early forestry ODA was to secure foreign forest resources by developing forestry industries such as pulp and paper factories (Neil, 1997; Reidar, 2000). This dispute related to genuine purpose of ODA was found in not only forestry but also in general ODA trend (Yoon et al., 2013).

While forestry researchers conducted their study relevant to forestry aid by experience or interview with forestry ODA projects, the purpose of general ODA including all sectors was more deeply studied by analyzing bilateral ODA allocation trend of main donors in statistical

\footnotetext{
Department of Forest Resources, Chungnam National University, Daejeon-Si 305-764, Republic of Korea

${ }^{2}$ Professional Graduate School of Disaster Prevention, Kangwon National University, Samcheok-Si, Gangwon-Do 245-711, Republic of Korea

* Corresponding author (E-mail:gspark@cnu.ac.kr)
}

way. The researches on allocation of ODA were well studied from 1990s. In those studies, characteristics of recipient countries such as poverty rates, GDP per capital, infant mortality, government effectiveness, import and export amount, corruption index, trade openness index, history of colony and etc. which may affect ODA allocation of donor countries were selected in order to investigate the relationship of allocated amount of recipient countries and them.

Their statistical analysis methods were slightly different each other causing controversy over their results. However, the result in common indicated that ODA trend may be allocated based on particularly selective tendency with strategic purposes such as economical, diplomatic or political purpose (Lee, 2011; David and Victoria, 2006; Mckinlay and Little, 1979; Easterly 2007). Ironically, ODA trend with strategy purposes was hard to be detected in publications written by donor countries because they tend to cover its strategy purpose with humanitarian purpose.

Korean forestry ODA has been hardly studied by researchers due to its short history and week competitiveness compared to the other sectors of ODA unlike Japan. It is important to understand current trend of Korean forestry ODA allocation. If Korean forestry ODA does not have proper direction to advance its role to play, the competitiveness will be gradually worse and be critically evaluated by researchers, the other donors, and government.

Thus, the purpose of this study was to investigate trend of Korean forestry ODA allocation. In this study, the proportion of forestry ODA allocation by recipient continents was compared between Korea and OECD/ DAC. And factors which may affect KFOA were analyzed by statistical analysis method. Finally, implication on developmental direction of Korean forestry ODA was 
discussed.

\section{METHODS}

\section{Data collection}

Study data from 2006-2011 was collected from the following sources (Table 1). Distances from capitals of recipient countries to Seoul were calculated by great circle distances between capital cities program. Forest area and forest conversion rate were collected from FAO data. Corruption index by transparency international ranges from the lowest 1 to the highest 10. Status of bilateral forestry cooperation with recipient countries was collected from Korea Forest Service data. GDP per capital and income level of countries were collected from World Bank. Data of forest product import and export was from Korean ministry of agriculture. Allocated amount of forestry ODA from 2006 to 2011 was collected from OECD because Korean forestry ODA was officially recorded in OECD statistic from 2006.

\section{Analysis}

The selected factors which may affect KFOA were eight. Distances, amount of product import \& export, corruption index, GDP per capital, and income level of each recipient country were selected due to its frequent appearance of previous studies (David and Victoria, 2006; Mckinlay and Little, 1979; Easterly, 2007; Lee, 2011). Forest area and forest conversion rate, and bilateral forestry cooperation were selected due to distinct characteristics of forestry ODA. A dependent variable used in all statistical analysis was the allocation amount of Korean forestry ODA to each recipient country from 2006-2011. SPSS 20 version was used for all statistical analysis and significant level was 0.1. Analysis methods were as followings.

1) The relationship between the KFOA amount of each recipient countries and distance, GDP, corruption, forest area, forest conversion rate, and forest product import and export was analyzed by correlation analysis.

2) The difference of received ODA amount in the income levels and bilateral forestry cooperation of recipient countries was analyzed by One-Way ANOVA and t-test. In case, Levene statistic for test of homogeneity of variances was below than $\mathrm{p}<0.05$, a result of Welch or Brown-Forsythe test was used (Brown and Forsythe,
1974).

3) To find out the most determinant factor among eight variables, those variables which showed $p<0.1$ from first and second analysis were analyzed together by dummy regression analysis and ANCOVA (Miller and Chapman, 2001).

\section{RESULTS AND DISCUSSION}

\section{Forestry ODA allocation of Korea and OECD/ DAC}

According to OECD statistical data, there were 24 recipient countries of Korean forestry ODA from 20062011. Mongolia received the most amount of Korean forestry ODA followed by China, Indonesia, Philippine, Myanmar, and etc. among recipient countries. Number of recipient countries was 13 in Asia, 6 in America, 3 in Africa, and 1 in Oceania by continent. About 98.1\%, 1.1\%, $0.4 \%$, and $0.4 \%$ of Korean forestry ODA amount were allocated to Asia, America, Africa, and Oceania during 2006-2011, respectively. On the contrast to Korean forestry ODA mostly concentrated on Asia, OECD/DAC increased its allocation to Africa by 26\% during 19992011 after its decreasing allocation trend during 19731998 (Fig. 1). Considerable numbers of countries in Africa have been suffering from the worst poverty rate and the highest forest conversion rate (Jeong, 2010). Korean forestry ODA is needed to be extended into Africa in order to solve their forestry related problems,

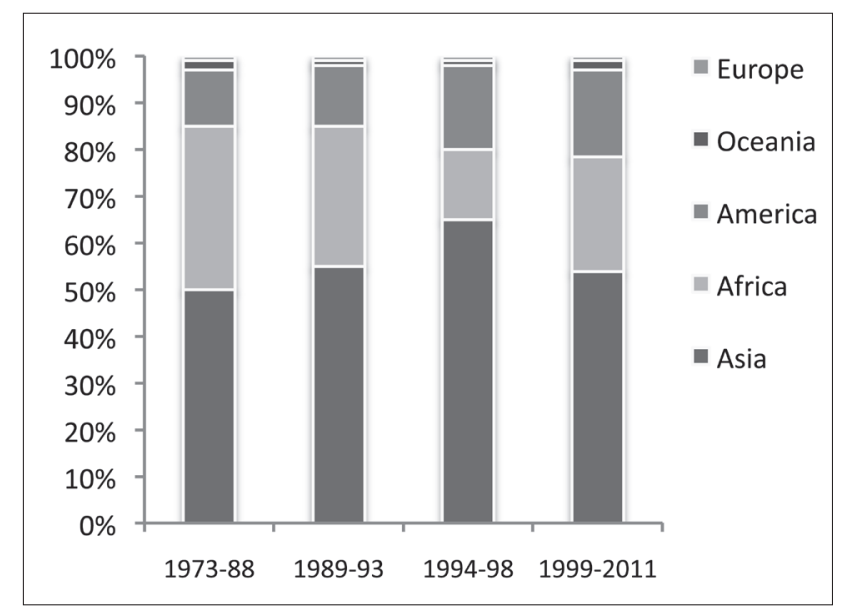

Fig. 1. Forestry ODA allocation of OECD/DAC by continents.

Table 1. Data source of variables used in statistical analysis

\begin{tabular}{ll}
\hline \multicolumn{1}{c}{ Variables } & \multicolumn{1}{c}{ Source (2006-2011) } \\
\hline $\begin{array}{l}\text { Allocated amount of Korean forestry ODA } \\
\text { Distance }\end{array}$ & OECD (http://stats.oecd.org/Index.aspx?DatasetCode=CRSNEW) \\
Forest area \& Conversion rate & Great Circle Distances between Capital Cities program \\
Income level of countries \& GDP per capital & FAO (http://faostat.fao.org/site/377/DesktopDefault.aspx?PageID=377) \\
Corruption Index & World Bank (http://data.worldbank.org/indicator/NY.GDP.PCAP.CD) \\
Forestry product amount of Import \& Export & $\begin{array}{l}\text { Ministry of Agriculture (http://www.kati.net/sta/staRes1.do?menuCode=120 } \\
\text { \&parentCode=1\&url=\%2Fsta\%2FstaRes1\&topMenuCode=120) }\end{array}$ \\
Status of Bilateral forestry cooperation & Korea Forest Service report, 2012 \\
\hline
\end{tabular}


not focusing on only Asia.

\section{Factors which may affect KFOA}

2.1 Distance, GDP, Corruption, forest area, FCR, and FPIE

Correlation analysis was conducted to see if distance, GDP, corruption, forest area, FCR (Forest Conversion Rate), and FPIE (Forest Product Import and Export) affected KFOA (Korean Forestry ODA Allocation). The table 3 shows basic statistics of 24 recipient countries. The results of correlation analysis are shown as the following table 3. GDP per capital, corruption index, and forest conversion rate showed no significant correlation with the amount of Korean forestry ODA. However, forest area, the amount of imported and exported forest product, and distance showed $\mathrm{p}>0.31, \mathrm{p}>0.22$, and p $>0.38$, respectively.

\subsection{Bilateral forestry cooperation and income levels of countries}

Countries with bilateral forestry cooperation are Mongolia, Ecuador, Cambodia, Indonesia, Myanmar, Philippine, and China. The difference of countries with bilateral forestry cooperation and non-countries in allocated amounts was analyzed by t-test. Levene statistic for test of homogeneity of variances was below than 0.05. Thus, a result of welch test was used. It indicated that countries with bilateral forestry cooperation received more amount of Korean forestry ODA than non-countries $(p<0.05)$. Actually about $90 \%$ of Korean forestry ODA amount from 2006-2011 was allocated to only 4 countries with bilateral forestry cooperation which were Mongolia, China, Indonesia, and Philippine. Table 4 shows difference of received ODA amount in two groups.

The difference of received ODA amount between recipient countries by income levels was not statistically significant. The table 5 and table 6 show results of ANOVA and a list of countries by income levels.
GDP per capital and allocated amount of Korean forestry ODA also showed no correlation showing positive correlation coefficient as shown above. This indicated that the other factors may be reflected in allocation of forestry ODA rather than poverty levels of recipient countries.

\subsection{The most influential variable for KFOA}

Distance, FPIE, and forest area which showed statistical correlation with allocated amount of Korean forestry ODA and status of bilateral forestry cooperation were selected as independent variables for dummy regression analysis. The value of $\mathrm{R} 2$ and $\mathrm{p}$-value were 0.543 and 0.005 , respectively. Each VIF of variables was less than 10. The highest Beta value of standarized coefficients among four independent variables was status of bilateral forestry cooperation.

In result of ANCOVA, the status of bilateral forest cooperation between Korea and recipient countries turned out the only significant factor $(\mathrm{p}<0.05)$ for allocation of Korean forestry ODA. And the other variables such as trade amount of imported \& exported forest product, distance, and forest area were not statistically significant ( $\mathrm{p}>0.05)$.

As a result of ANCOVA and dummy regression analysis, it is thought that bilateral forest cooperation was the most determinant factor for the allocation of Korean forestry ODA among 8 variables. Korea Forest Service has been setting up the framework for public and private sectors which intend to make inroad in overseas in order to secure foreign forest resources. As that movement, the number of bilateral forestry cooperation with developing countries has increased (Korea Forest Service, 2008). And besides, the statement "Building cooperative relationship with various countries for plantation business in order to secure stable forest resources" was specified in Country Partnership Strategy (CPS) for Solomon Islands which was established by Korea International

Table 2. Rank of Korean forestry ODA allocation by recipient countries

\begin{tabular}{|c|c|c|c|c|c|}
\hline Rank & Recipient country & $\begin{array}{c}\text { KFOA }(\$) \\
\text { Sum of } 2006-2011\end{array}$ & Rank & Recipient country & $\begin{array}{c}\text { KFOA }(\$) \\
\text { Sum of } 2006-2011\end{array}$ \\
\hline 1 & Mongolia & $12,095,327$ & 13 & Kyrgyzstan & 68,042 \\
\hline 2 & Indonesia & $9,412,123$ & 14 & Tanzania & 45,227 \\
\hline 3 & China & $6,157,923$ & 15 & Peru & 22,744 \\
\hline 4 & Philippine & $4,707,104$ & 16 & Ethiopia & 15,250 \\
\hline 5 & Myanmar & $1,679,989$ & 17 & Haiti & 13,939 \\
\hline 6 & Cambodia & 557,532 & 18 & Afghanistan & 13,540 \\
\hline 7 & Dominica & 219,649 & 19 & Pakistan & 12,050 \\
\hline 8 & Solomon & 140,564 & 20 & Honduras & 8,750 \\
\hline 9 & Laos & 137,160 & 21 & Ecuador & 7,828 \\
\hline 10 & Thailand & 136,545 & 22 & Zambia & 7,630 \\
\hline 11 & Argentina & 117,314 & 23 & Uzbekistan & 5,970 \\
\hline 12 & Rwanda & 90,153 & 24 & East Timor & 5,880 \\
\hline
\end{tabular}

*Multilateral and unclassified ODA was not included, provisional agreement amount, Portion of allocation by continent is Asia $98.1 \%$, America $1.1 \%$, Oceania $0.4 \%$, Africa and $0.4 \%$, Source: OECD statistic webpage 
Table 3. Status of AKFO, distance, corruption, FPIE, GDP per Capital, Forest area, and FCR by each recipient country

\begin{tabular}{|c|c|c|c|c|c|c|c|}
\hline Countries & $\mathrm{AKFO}(\$)$ & $\begin{array}{l}\text { Distance } \\
(\mathrm{km})\end{array}$ & $\begin{array}{l}\text { Corruption } \\
\text { Index }\end{array}$ & $\operatorname{FPIE}(\$)$ & $\begin{array}{c}\text { GDP per } \\
\text { Capital (\$) }\end{array}$ & $\begin{array}{l}\text { Forest area } \\
\text { (ha) }\end{array}$ & $\begin{array}{l}\text { FCR } \\
(\%)\end{array}$ \\
\hline Afghanistan & 2,257 & 5,123 & 1.8 & 1,548 & 306 & 1,350 & 0 \\
\hline Argentina & 19,552 & 19,415 & 2.8 & $2,287,538$ & 6,158 & 30,244 & -.80 \\
\hline Cambodia & 92,922 & 3,630 & 1.8 & 544,534 & 587 & 10,553 & -1.31 \\
\hline China & $1,026,321$ & 954 & 3.4 & $689,146,952$ & 2,601 & 197,022 & -1.51 \\
\hline Dominica & 36,608 & 13,534 & 3.0 & 109 & 3,915 & 1,972 & 0 \\
\hline East Timor & 980 & 4,806 & 2.5 & - & 517 & 781 & -1.41 \\
\hline Ecuador & 1,305 & 15,101 & 2.3 & 31,828 & 3,158 & 10,557 & -1.84 \\
\hline Ethiopia & 2,542 & 9,242 & 2.6 & 348 & 245 & 12,789 & -1.09 \\
\hline Haiti & 2,323 & 13,453 & 1.8 & 10,491 & 533 & 104 & -.77 \\
\hline Honduras & 1,458 & 13,246 & 2.5 & 2,240 & 1,632 & 5,612 & -2.10 \\
\hline Indonesia & $1,568,687$ & 5,283 & 2.4 & $295,016,324$ & 1,788 & 96,689 & -.56 \\
\hline Kyrgyzstan & 11,340 & 4,402 & 2.1 & 217,541 & 743 & 912 & 1.84 \\
\hline Laos & 22,860 & 3,216 & 2.4 & 984,584 & 697 & 16,025 & -.49 \\
\hline Mongolia & $2,015,888$ & 1,999 & 2.9 & 764,303 & 1,425 & 11,185 & -.73 \\
\hline Myanmar & 279,998 & 3,790 & 1.6 & $10,268,972$ & 994 & 32,857 & -.93 \\
\hline Pakistan & 2,008 & 4,820 & 2.3 & $1,646,320$ & 809 & 1,838 & -2.29 \\
\hline Peru & 3,791 & 16,298 & 3.5 & 215,943 & 3,625 & 68,496 & -1.90 \\
\hline Philippine & 784,517 & 2,614 & 2.5 & $6,854,056$ & 1,538 & 7,473 & -.74 \\
\hline Rwanda & 15,026 & 10,743 & 3.1 & 36,949 & 368 & 401 & 2.38 \\
\hline Solomon & 23,427 & 6,248 & 2.8 & $23,327,601$ & 1,031 & 2,233 & -.25 \\
\hline Tanzania & 7,538 & 10,259 & 2.8 & 20,386 & 423 & 34,840 & -1.15 \\
\hline Thailand & 22,758 & 2,311 & 3.5 & $104,203,852$ & 3,635 & 18,972 & - \\
\hline Uzbekistan & 995 & 4,888 & 2.2 & 93,998 & 808 & 3,282 & .12 \\
\hline Zambia & 1,272 & 11,792 & 2.7 & 495 & 853 & 50,051 & -.33 \\
\hline
\end{tabular}

*AKFO: Allocated amount of Korean Forestry ODA, FPIE: Forest product Import \& Export, FCR: Forest Conversion Rate. All values above are 6 years average from 2006-2011.

Table 4. The statistical correlation between the amount of KFOA and distance, GDP, corruption, forest area, FCR, and FPIE

\begin{tabular}{|c|c|c|c|c|c|c|}
\hline & $\mathrm{AKFO}$ & Distance & $\begin{array}{l}\text { Corruption } \\
\text { Index }\end{array}$ & FPIE & $\begin{array}{c}\text { GDP per } \\
\text { Capital }\end{array}$ & Forest area \\
\hline \multirow{2}{*}{ Distance } & -.426 & 1 & & & & \\
\hline & $(.038)^{* *}$ & & & & & \\
\hline \multirow{2}{*}{$\begin{array}{l}\text { Corruption } \\
\text { Index }\end{array}$} & .150 & .162 & 1 & & & \\
\hline & $(.485)$ & $(.449)$ & & & & \\
\hline \multirow{2}{*}{ FPIE } & .476 & -.349 & .344 & 1 & & \\
\hline & $(.022)^{* *}$ & $(.102)$ & $(.108)$ & & & \\
\hline \multirow{2}{*}{$\begin{array}{c}\text { GDP per } \\
\text { Capital }\end{array}$} & .043 & .477 & .508 & .175 & 1 & \\
\hline & $(.842)$ & $(.018)$ & $(.011)$ & $(.425)$ & & \\
\hline \multirow{2}{*}{ Forest area } & .442 & -.136 & .404 & .911 & .265 & 1 \\
\hline & $(.031)^{* *}$ & $(.526)$ & $(.050)$ & $(.000)$ & (.211) & \\
\hline \multirow{2}{*}{ FCR } & .106 & -.256 & .182 & .351 & -.127 & .216 \\
\hline & (.630) & $(.239)$ & $(.406)$ & (.109) & $(.562)$ & $(.322)$ \\
\hline
\end{tabular}

AKFO: Allocated amount of Korean Forestry ODA, FPIE: Forest product Import \& Export, FCR: Forest Conversion Rate $* \mathrm{P}<0.1 * * \mathrm{P}<0.05, \mathrm{n}=24$ (average), Total sample number $=150$, A dependent variable : AKFO 
Table 5. Difference of allocated amount of Korea forestry ODA between countries with bilateral forest cooperation and non-countries

\begin{tabular}{lrrrrr}
\hline \multicolumn{1}{c}{ Group } & $\mathrm{n}$ & means & \multicolumn{1}{c}{ SE } & $\mathrm{t}$ & $\mathrm{p}$ \\
\hline Bilateral forest cooperation & 7 & 824233.96 & 289699.68 & 2.809 & $.031^{* * *}$ \\
None & 17 & 10396.15 & 2661.44 & & \\
\hline
\end{tabular}

$* \mathrm{P}<0.1 * * \mathrm{P}<0.05, \mathrm{n}=24$ (average), Total sample number=150, A dependent variable: AKFO, Welch test

Table 6. Difference of allocated amount of Korea forestry ODA between countries by income levels

\begin{tabular}{lrcrrr}
\hline \multicolumn{1}{c}{ Income levels } & $\mathrm{n}$ & means & $\mathrm{SE}$ & $\mathrm{F}$ & $\mathrm{p}$ \\
\hline Low income & 5 & 24773.54 & 17220.21 & .731 & .493 \\
Lower middle income & 13 & 362474.66 & 187963.98 & & \\
Upper middle income & 6 & 185055.65 & 168336.63 & \\
\hline
\end{tabular}

$* \mathrm{P}<0.1 * * \mathrm{P}<0.05, \mathrm{n}=24$ (average), Total sample number=150, A dependent variable: AKFO, Brown Forsyther test

Table 7. Classifications of countries by income levels

\begin{tabular}{ll}
\hline \multicolumn{1}{c}{ Income levels } & \multicolumn{1}{c}{ Countries } \\
\hline Low income & Afghanistan, Cambodia, Haiti, Rwanda, Kyrgyzstan \\
Lower middle income & Pakistan, Zambia, Indonesia, Laos, Myanmar, Philippine, East Timor, Mongolia, \\
Epthiopia, Tanzania, Solomon islands, Honduras, Uzbekistan
\end{tabular}

Source: World Bank, 2012

Table 8. The most influential variable for AKFO among distance, FPIE, forest area, and bilateral forestry cooperation by dummy regression analysis

\begin{tabular}{|c|c|c|c|c|c|c|c|c|}
\hline & \multirow{2}{*}{$\begin{array}{c}\begin{array}{c}\text { Standardized } \\
\text { coefficients }\end{array} \\
\text { B }\end{array}$} & \multirow{2}{*}{$\mathrm{t}$} & \multirow{2}{*}{$\mathrm{p}$} & \multicolumn{2}{|c|}{ Collinearity statistics } & \multirow{2}{*}{$\mathrm{R}^{2}$} & \multirow{2}{*}{$\mathrm{F}$} & \multirow{2}{*}{$\mathrm{p}$} \\
\hline & & & & Tolerance & VIF & & & \\
\hline (Constant) & & 3.729 & .002 & & & \multirow{5}{*}{.543} & \multirow{5}{*}{5.353} & \multirow{5}{*}{$.005 * *$} \\
\hline $\begin{array}{c}\text { Bilateral } \\
\text { Cooperation }\end{array}$ & -.535 & -2.865 & $.010 * *$ & .727 & 1.376 & & & \\
\hline Distance & -.188 & -.936 & .362 & .629 & 1.589 & & & \\
\hline FPIE & .048 & .106 & .917 & .124 & 8.040 & & & \\
\hline Forest area & .155 & .355 & .726 & .134 & 7.476 & & & \\
\hline
\end{tabular}

AKFO: Allocated amount of Korean Forestry ODA, FPIE: Forest Product Import and Export, $* \mathrm{P}<0.1 * * \mathrm{P}<0.05, \mathrm{n}=24$ (average), Total sample number $=150$, A dependent variable: AKFO,

Table 9. The most influential variable for AKFO among distance, FPIE, forest area, and bilateral forestry cooperation by ANCOVA

\begin{tabular}{ccccc}
\hline & SS & MS & F & p \\
\hline Forest area & $2.16 \mathrm{E}+10$ & $2.16 \mathrm{E}+10$ & .126 & .726 \\
FPIE & $1.91 \mathrm{E}+09$ & $1.91 \mathrm{E}+09$ & .011 & .917 \\
Distance & $1.50 \mathrm{E}+11$ & $1.50 \mathrm{E}+11$ & .876 & .362 \\
Bilateral forest cooperation & $1.41 \mathrm{E}+12$ & $1.41 \mathrm{E}+12$ & 8.211 & $.010^{* * *}$ \\
Error & $3.08 \mathrm{E}+12$ & $1.71 \mathrm{E}+11$ & & \\
\hline
\end{tabular}

AKFO: Allocated amount of Korean Forestry ODA, FPIE: Forest Product Import and Export, $* \mathrm{P}<0.1 * * \mathrm{P}<0.05, \mathrm{n}=24$ (average), Total sample number=150, A dependent variable: AKFO, 
Cooperation Agency (KOICA, 2011). Accordingly, it is thought that Korean Forestry ODA was partially conducted based on strategic purposes by allocating more amount of ODA to countries with bilateral forestry cooperation.

In addition, knowledge of forest experts or forest public servants from both countries was needed when forestry ODA was implemented. Exchanges of forestry public servants or forestry experts have been more active and forest resources were better understood in those countries with long cooperative relationship. Thus, those advantages on smooth ODA projects may influence on allocation of Korean forestry ODA as well.

\section{CONCLUSIONS}

As a result of this study, (1) Korea was selective in targeting Asia which received 98\% of KFOA, and (2) The status of bilateral forest cooperation between Korea and recipient countries was the most determinant factor for allocation of Korean forestry ODA among the other variables. It is thought that some economic or diplomatic strategic purposes were partially reflected in allocation of Korean forestry ODA. This phenomenon is not proper to the genuine purpose of ODA and this tendency could end up affecting evaluation of forestry ODA in negative way. Forestry ODA with purpose based on only economical or diplomatic strategies should be refrained. Therefore, Korean Forestry ODA needs to reduce its tendency of selectivity for Asia and countries with bilateral countries, extending its allocation into Africa with the highest forest conversion rate and poverty rate.

\section{REFERENCES}

Arnold, J. M. 2001 Forestry, poverty and aid. CIFOR occasional paper, 33: 1-17

Brown, M. B. and A. B. Forsythe 1974 Robust test for equality of variances. Joumal of the American statistical association, 69: $364-367$

David, D. and L. Victoria 2006 The increasing selectivity of foreign aid 1984-2003. World development, 34(12): 2034-2046

Easterly, W. 2007 Are aid agencies improving?. Economic policy. 22(52): 633-678

KOICA 2011 Country partnership strategy for Vietnam, Ghana, Solomon islands 2011-2015. KOICA, p. 157

Jeong J. S. 2010 The implication of Korean ODA and international ODA for desertification of Africa. Korea association of international development and cooperation, 2(2): 95-126

Korea Forest Service 2008 General plan for oversea forest resource development 2008-2017. Korea Forest Service, p. 36

Korea Forest Service 2012 status of Korean bilateral forestry cooperation agreement. Korea Forest Service, p. 1

Lee, W. Y. 2011 Aid allocation policies and practice: DAC members and Korea. Korea development institute, 33(4): 51-83

Mckinlay, R. D. and R. Little 1979 The U.S aid relationship: A test of the recipient need and the donor interest models. Political Studies, 27(2): 236-250

Miller, G. A. and J. P. Chapman 2001 Misunderstanding analysis of covariance. Journal of abnormal psychology, 110(1): 40-48

Neil, B. 1997 International development assistance in forestry and land management: the process and the players. Commonwealth forestry review, $\mathbf{7 6}(1)$ : $61-66$

Reidar, P. 2000 Assistance to forestry: what have we learnt?. International forestry review, 2(3): 218-224

White, A. and A. Martin 2002 Who owns the world's forest; Forest tenure and public forests in transition, $1^{\text {st }}$ ed. Forest trend. Press, Washington DC (USA) pp. 5-6.

Yoon, J. Y., G. S. Park, S. B. Kim, J. W. Lee, Y. J. Sung, S. J. Lee, B. H. Park and G. W. Jang 2013 A study on the direction of Korean official development assistance in forestry. CNU journal of agricultural science, $\mathbf{4 0}(1)$ : 19-26 